\title{
"Za slobodu nas Krist oslobodi« (Gal 5,1) - Poimanje slobode u Poslanici Galaćanima (II.: Sloboda kao sloboda od Zakona)
}

Marinko Vidović mvidovic@kbf-st.hr

https://orcid.org/0000-0003-0746-023X https://doi.org/10.31192/np.18.2.11

UDK: $27-248.48$

$2-423.4$

Pregledni članak / Review Primljeno: 3. veljače 2020. Prihvaćeno: 24. veljače 2020.

Budući da je vjera, a time i sloboda Galaćana ugrožena pokušajem vraćanja pod Mojsijev zakon, oslanjajući se na biblijsko pripovijedanje o Abrahamu, Pavao progovara o slobodi kao slobodi od Mojsijeva zakona. Temeljna mu je tvrdnja da Zakon nije početak povijesti spasenja nego Abrahamova vjera koja se oslonila na Božje obećanje. U tomu smislu Zakon je bio nadodan radi prekršaja, radi maloljetnosti čovječanstva, bio je nadziratelj u smislu privremenosti $i$ svojevrsne prisile svojih podložnika, bio je zarobljavajuća snaga od koje je trebalo osloboditi čovjeka. Tu je slobodu Bog ostvario u Kristu koji je jedini istinski Potomak Abrahamov. Oni koji su u Kristu ostvaruju abrahamovski odnos s Bogom, odnos povjerenja i oslanjanja na obećanje, odnos slobode kojemu Zakon nije služio nego ga ugrožavao. Sloboda se ne ostvaruje pod izvanjskom prisilom, nego nutarnjim opredjeljenjem za Božje postupanje koje je nošeno njegovim obećanjem. U ovomu dijelu rada slijedimo Pavlovo razmišljanje u Poslanici Galaćanima o slobodi koju Bog nudi u Kristu i koja je oslonjena na obećanje kao put ostvarenja istinske slobode u odgovornosti. S Abrahamom kao modelom Božjega postupanja sa čovječanstvom i ljudskog odgovora na Božju ponudu i obećanje, Pavao određuje slobodu kao slobodu od prisile Zakona.

Ključne riječi: Abraham, obećanje, prisila, sloboda, vjera, zakon.

\footnotetext{
* Prof. dr. sc. Marinko Vidović, Sveučilište u Splitu, Katolički bogoslovni fakultet, Zrinsko-frankopanska 19, HR-21000 Split.
} 


\section{Uvod}

U prvoj cjelini ovoga rada vidjeli smo ukorijenjenost Pavlova govora o slobodi u konkretno stanje crkava u Galaciji i njezinu određenost kristološkom vjerom, odnosno prihvaćenjem Božjega spasiteljskoga zahvata u Kristu. ${ }^{1} \mathrm{U}$ ovoj drugoj cjelini želimo istražiti njegov govor o slobodi kao oslobođenosti od Mojsijeva zakona, od prisile Zakona, čemu je Pavao posvetio znatan dio Poslanice Galaćanima, dok ćemo u trećoj cjelini rada ${ }^{2}$ istražiti Pavlov govor o slobodi kao statusu ne-robovanja i afirmativnoj opredijeljenosti $z a$.

\section{Sloboda od Zakona: sloboda bez prisile}

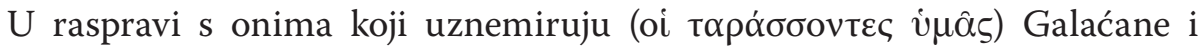

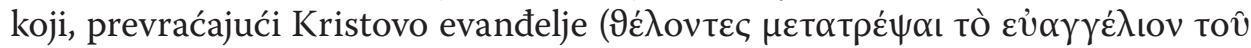
Xpıбтô̂, 1,7), traže od njih da uz Krista prihvate i Zakon kao temelj ispravnoga odnosa s Bogom i kao normu vlastite slobode, Pavao, nakon što je opisao svoje pristajanje uz Evanđelje $(1,11$ - 2,17), poseže za Abrahamovim likom da bi pokazao i dokazao drugotnu ulogu Zakona u Božjemu spasiteljskom naumu, njegovu donekle porobljivačku i prisilnu, a ne osloboditeljsku snagu $(3,1-4,17)$. Rezonira na temelju Pisma i to uglavnom na deduktivan način.

Abraham je i u židovstvu važio kao osoba paradigmatskih odnosa s Bogom. ${ }^{3}$ Pavao to prihvaća i njegovu pradigmatičnost tumači u posve drugom smislu od onoga kako se tumačila u židovstvu. Židovstvo se, posebno intertestamentarni judaizam II. stoljeća prije Krista do I. stoljeća po Kristu, svojski trudilo dokazivati da je i Abraham u svom postupanju zavisio i bio oslonjen na Toru, da je upravo zbog te oslonjenosti bio pravednik pred Bogom zbog čega je i bio uključen u Božji spasiteljski naum. Raznim spekulacijama o Tori, o njezinoj preegzisteniciji i posredovanju u stvaranju svijeta, židovstvo je u tomu i uspijevalo. ${ }^{4}$ Pavao to ne prihvaća i kani obraniti slobodu Evanđelja od pristajanja uz Zakon kao put spasenja.

${ }^{1}$ Marinko Vidović, »Za slobodu nas Krist oslobodi« (Gal 5,1) - Poimanje slobode u Poslanici Galaćanima, I.: Sintagma u povijesnom kontekstu poslanice i kristološke vjere, Nova prisutnost, 18 (2020) 1, 115-126; https://doi.org/10.31192/np.18.1.9.

${ }^{2}$ Koja će biti objavljena u sljedećem br. ovoga časopisa.

${ }^{3}$ Usp. Adalbert REBIĆ, Abraham naš otac u vjeri. Povijest, vjera i teologija, Bogoslovska smotra, 76 (2006) 3, 513-529.

${ }^{4}$ Usp. Hermann L. STRACK, Paul BILLERBECK, Kommentar aus Talmud und Midrasch, III, 186-201. Dovoljno je ovdje navesti samo Knjigu Jubileja: »U tvom sjemenu [Izaku] bit će blagoslovljeni svi narodi zemlje, jer je tvoj otac slušao moju riječ i vršio je (...) moje zapovijedi i moje zakone« $(24,11)$. Slično i Babilonski Talmud, Joma 28b; Adalbert REBIĆ, Abraham prema židovskoj rabinskoj egzegezi, Bogoslovska smotra, 76 (2006) 3, 595-615; opširnije, Meinrad LIMBECK, Die Ordnung des Heils. Untersuchungen zum Gesetzverständnis des Frühjudentums, Düsseldorf, 1971. 
Poštujući dinamičnost povijesti spasenja, postupnost i uronjenost spasenja u povijest, Pavao poseže za Abrahamovim likom. ${ }^{5}$ Želi dokazati da se povijest odnosa s Bogom ne gradi na Zakonu i njegovim odredbama, nego na obećanju i vjerničkom oslanjanju na obećanje. Abraham je povjerovao Bogu, kako piše u Post 5,6, i to mu je bilo uračunato u pravednost. Pavao polazi od toga teksta gdje se prvi put u govoru o Abrahamu pojavljuje pojam »vjera « i to zajedno s pravednošću i dokazuje Abrahamov status kao plod čiste Božje milosti, a ne nekakvih njegovih postignuća, zasluga i pobožnosti, ponajmanje njegove oslonjenosti na Zakon. Bog je uvažio Abrahamovo vjerničko oslanjanje na obećanje u njegovoj potpunoj slobodi i tim je oslanjanjem započeo povijest spasiteljskih odnosa s čovječanstvom. Abraham se već prethodno oslonio na Božje obećanje (usp. Post 12,2), na Božju vjernost kojoj nije imao ponuditi ništa drugo osim svoga pristanka, svoje vjere. Ta mu je vjera bila uračunata kao pravednost, kao ispravan odnos s Bogom koji obećava. Vjera je ovdje mišljena kao povjerenje, a ne kao vjernost Božjim zapovijedima, kako je tumačila židovska hermeneutika na

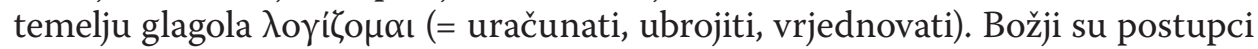
s ljudima oduvijek zamišljeni u relaciji obećanje-vjera, a ne Zakon-poslušno izvršavanje Zakona, uračunavanje djelâ. Luk spasenja se spaja u obećanju i njegovu ostvarenju. Abrahamu je obećan Potomak, a ne potomstvo, i Pavao, vrlo vještom rabinskom egzegezom koja ide do malih pojedinosti, ${ }^{6}$ zaključuje da taj Abrahamu obećani Potomak nije nitko drugi doli Isus Krist. Ta i Pismo ne govori o potomstvu kao množini, nego o Potomku u jednini. ${ }^{7}$ U tom se Potomku postaje Abrahamovom djecom, odnosno slobodnim sinovima Božjim.

Na temelju takvog rezoniranja, Pavao nužno dolazi do pitanja: A čemu onda Zakon ili, kako neki, ali manje točno, prevode, što je onda Zakona $(3,19)$ ? $^{8}$ Govoreći o Zakonu na temelju vjere i uvjerenja da je jedino u Kristu spasenje, ali i na temelju čisto povijesno-spasenjskog razmišljanja, u koje uvrštava čak i razmišljanje "po ljudsku «, Pavao na razne načine umanjuje ulogu Zakona. Najprije vremenski, jer je Zakon došao, bio je »pridodan« $(3,19)$ tek četiri stotine i trideset godina nakon Abrahama (usp. Izl 12,40 LXX). Potom funkcionalno, jer je Zakon dometnut »poradi prekršaja« i dan je »po posredniku, po anđelima« $(3,19)$, a ne izravno od Boga. ${ }^{10} \mathrm{Na}$ kraju, privremenošću i strogošću Zakona, jer je imao samo ulogu nadziratelja, koja prestaje onoga trenutka kada se pojavi onaj na koga je smjeralo obećanje i kojemu je nadziratelj trebao voditi $(3,23 \mathrm{~s})$.

${ }^{5}$ Za detaljnije tumačenje ovoga teksta usp. Marinko VIDOVIĆ, Abrahamov lik u argumentiranju spasenja po vjeri u Poslanici Galaćanima, Bogoslovska smotra, 73 (2003) 4, 533-575.

${ }^{6}$ Usp. Jean-Noël ALETTI, Saint Paul exégète de l'Écriture, u: René LAFONTAINE i dr. (ur.), L'Écriture âme de la théologie, Bruxelles, 1990, 37-59.

${ }^{7}$ Grč. riječ $\sigma \pi \eta ́ \rho \mu \alpha$ je zbirna imenica, ali je Pavao tumači kao jedninu. To mu je jako važno u dokazivanju da je Abraham imao jednoga pravoga Potomka - Krista.

${ }^{8}$ Usp. Giuseppe BARBAGLIO, La teologia di Paolo. Abbozzi in forma epistolare, EDB, Bologna, ${ }^{2} 2008,493$.

9 Usp. Marinko VIDOVIĆ, Pavlov govor »po ljudsku«, Bogoslovska smotra, 78 (2008) 3, 505-531.

${ }^{10}$ Usp. Albert VANHOYE, Un médiateur des anges en Ga 3,19-20, Biblica, 59 (1978) 403-411. 
Kao takav, Zakon je svakako imao podređenu ulogu u procesu Božjega spasiteljskog djela, štoviše, bio je izvorom prokletstva jer je izricao prokletstvo svima koji ga nisu, ili ga nisu mogli potpuno izvršavati (3,10; usp. Pnz 27,26) ${ }^{11}$ i koji su stoga njegovi prekršitelji.

Manjak Zakona ipak nije, kako se to na prvi pogled može učiniti, samo u tomu što se kršenjem pojedinih njegovih zapovijedi, pa i najmanje, može reći da netko nije vršitelj Zakona. ${ }^{12}$ Njegov manjak je upravo u tomu što je naglasak stavljao na vršenje, ${ }^{13}$ na čovjekove mogućnosti i sposobnosti, a ne na Božju milost. Najveći manjak Zakona je u tomu što i on pripada u svijet prokletstva, svijet iz kojega čovjeka treba izvući, svijet podređenosti grijehu kao nad-osobnoj sili koja djeluje u povijesti. Spasenjsko pouzdanje u Zakon, što i izražava Pavlova šifra »djela Zakona «, ${ }^{14}$ izraz je nepovjerenja u sveobuhvatnost Kristova spasiteljskoga djela, odbacivanje Krista (usp. 5,2) i ispad iz milosti (usp. 5,4). Čovjeka je trebalo osloboditi upravo od takvoga oslanjanja samo na sebe i svoje mogućnosti, što i jest temeljni grijeh koji mu donosi samo prokletstvo. Možemo reći da je najveće prokletstvo u koje čovjek zapada prisila samoostvarenja.

Zakon ne posreduje spasenje, nego je pridodan radi prekršaja, točnije, u vidu prekršaja. Onaj koji ga je dao imao je na umu prekršaj. Zakon je trebao samo omogućiti čovjeku spoznaju njegova stanja pred Bogom, njegovu uronjenost $u$ zlo i grijeh. I zlo i grijeh upravo po zakonskoj spoznaji postaju prekršaj, odnosno Zakon izriče i opravdava pravedni Božji sud nad svim ljudskim pokušajima samoostvarenja, ali ne omogućuje spasenje. Zakon i nije dan da posreduje spasenje $(3,21)$. On »služi samo za opravdanje pravednih $(2,13)$, a ne grješnika «. ${ }^{15}$ Spasenje, odnosno cjelovito ostvarenje, postiže se vjerničkim oslanjanjem na Božje djelovanje koje opravdava upravo grješnika. U tomu smislu Zakon je »slovo koje ubija«, a ne »Duh koji oživljuje« (2 Kor 3,7). Oslanjanje na Zakon izjednačeno je $s$ ispadom iz milosti $(5,4)$, što čovjeku pribavlja samo prokletstvo.

Za Pavla, Zakon nije ničim poboljšavao ljudsku situaciju, nego je samo očitovao, odnosno omogućavao je čovjeku da shvati svoju grješnost i izloženost

\footnotetext{
${ }^{11}$ Navodeći ovaj tekst Pavao ide protiv njegove nakane. Pisac Pnz energično potiče čitatelje na vršenje Zakona i izriče prokletstvo za one koji ne čine djela Zakona. Pavao ga rabi protiv onih koji žele činiti djela Zakona. Ne želi govoriti prvenstveno o onima koji opslužuju Zakon, nego o onima koji se baziraju na djelima Zakona, koji u Zakonu gledaju temelj i izvor svoga postojanja:

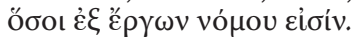

${ }^{12}$ Tako tumači Jakov u Jk 2,10.

${ }^{13}$ Navodeći Hab 2,4 (»Pravednik će od vjere živjeti«) i Lev 18,5 (»Tko ga vrši [Zakon], u njemu će naći život«), Pavao naglašava da je sustav vjere drugačiji od sustava Zakona. Zakon se bazira

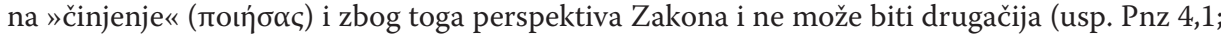
6,24; 30,16; Ez 20,11).

${ }^{14}$ Različita su tumačenja ovoga Pavlova izričaja: 1. samospasavanje bez milosti (Augustin, Luther, Bultmann, Käsemann); 2. pripadnost židovstvu po obrezanju, opsluživanju subote i prehrambenih propisa (»identity markers«, J. D. G. Dunn); 3. djela koja Zakon proizvodi, a ne propisuje ili zahtijeva (L. Gaston). Usp. Romano PENNA, Le opere della legge in Paolo e nel manoscritto qumraniano 4QMMT, u: isti, Vangelo e inculturazione. Studi sul rapporto tra rivelazione e cultura nel Nuovo Testamento, Cinisello Balsamo, 2001, 512-535, 517-521.

${ }^{15}$ Ulrich WILCKENS, Der Brief an die Römer I, EKK VI/I, Zürich i dr., 1978, 132-133.
} 
pravednoj Božjoj osudi - srdžbi. Zakon je uvijek sposoban staviti pod prokletstvo i ubiti. To je učinio i Kristu, ali on je to prokletstvo preuzeo iz ljubavi za

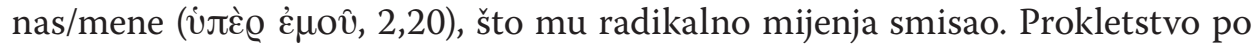
sebi označava odijeljenost od Boga koja je uzrokovana suprotstavljanjem Bogu. Posljedično, ono označava i prekid međuljudskih odnosa i dobrohotnosti među ljudima. Međutim, kad je takvo stanje preuzeto u korist drugih iz ljubavi, onda nije znak i izraz suprotstavljanja Bogu, nego, suprotno tomu, poslušnosti $u$ ljubavi koja dolazi od Boga. U tomu svjetlu Kristovo prokletstvo, njegovo »davanje samoga sebe $[. .$.$] po volji Boga, Oca našega« (1,4)$ postaje izvorom novih dobrohotnih odnosa s Bogom i sa svima. Razlog tomu nipošto nije Zakon, nije ni podnesena smrt, nego samo dobrohotna snaga ljubavi. Iz toga se vidi da Pavao ne kritizira Zakon samo na predlošku (ne)postignuća pred Bogom, nego i na predlošku savezničkoga dioništva ${ }^{16}$ odnosno zajedništva s Bogom. Ono se ostvaruje samo snagom ljubavi. Krist je postao prokletstvo (usp. 3,13) iz solidarnosti s nama, ${ }^{17}$ odnosno nas uključuje u svoje samodarivanje, omogućujući nam da umremo svojoj prošlosti, a živimo s njim i u njemu novim životom (2,19-20).

Zakon nije sposoban oživljavati, odnosno dati život onomu tko ga nema. ${ }^{18}$ On je sposoban samo za smrt, za kažnjavanje grješnika. Zakon djeluje na čovjeka izvana i nije unutarnje počelo njegova života. Govori o tomu što čovjek treba činiti, ali mu ne daje snagu da to i učini. Ne mijenja čovjeka nego ga ostavlja u onome u čemu ga je našao. U tomu smislu Zakon ne može zamijeniti obećanje, ali nije ni protiv obećanja. »Pismo je sve zatvorilo pod grijeh da se, po vjeri u Isusa Krista, obećano dade onima koji vjeruju« $(3,22)$. Glagol »zatvo-

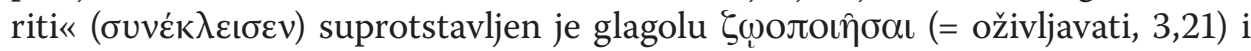
izražava slijepu ulicu iz koje nema izlaza. To je situacija dominacije grijeha, zarobljenosti grijehom (íjò ó $\mu \alpha \varrho \tau i ́ \alpha v)$, ali s pozitivnim ciljem: »Da se obećano dade onima koji vjeruju.« Zatvorenost pod Zakonom čuvala je za vjeru koja je trebala biti očitovana, tako da je Zakon bio nadziratelj ( $\left.\pi \alpha \_\alpha \gamma \omega \gamma o ́ \varsigma, ~ 3,24\right)$ prema Kristu, prema vjeri s kojom i po kojoj više nismo pod nadzirateljem. ${ }^{19}$

Prethodni govor o stanju čovječanstva sintagmom zatvorenosti »pod grijeh « sada je zamijenjen sintagmom »pod Zakonom«. Taj paralelizam je važan, premda ne izjednačava Zakon s grijehom. Ipak, biti pod Zakonom jednako je onomu biti pod grijehom u smislu da je u oba slučaja riječ o stanovitom porobljavanju

${ }^{16}$ Usp. Ed. Parish SANDERS, Paul, the Law and Jewish People, Philadelphia, 1983, 17-64; James D. G. DUNN, The Theology of Paul the Apostle, Edinburgh, 1998, 334-389.

${ }^{17}$ Takvim govorom Pavao smjera na Isusovu smrt na križu koja mu je morala u skladu s Pnz 21,23 izgledati kao Božje prokletstvo. Križ mu je kritika ljudske samodostatnosti i svih pokušaja da čovjek otkupi sam sebe vlastitim zalaganjem (usp. Felix PORSCH, Mnogo glasova jedna vjera. Teologija Novoga zavjeta, Zagreb, 1988, 133).

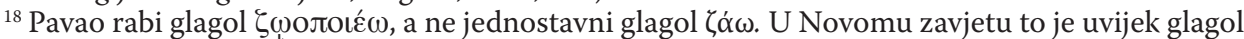
kojim se izriče Isusovo uskrišavanje ili buduće uskrišavanje onih koji su njegovi (usp. Rim 4,17; 8,11; 1 Kor 15,22.36.45; Iv 5,21 itd.).

${ }^{19}$ Usp. Norman H. YOUNG, Paidagogos: The Social Setting of a Pauline Metaphor, Novum Testamentum, 29 (1987) 1, 150-176. 
čovjeka. Sam prijedlog úró to jasno sugerira. Uostalom Pavao je jasno rekao da je »snaga grijeha upravo Zakon« (1 Kor 15,56), jer »bez Zakona grijeh je mrtav« (Rim 7,8-9). Nadziratelj je onaj koji čuva, stražari, prisiljava, zarobljava, jednostavno oduzima slobodu koja se dobiva tek po vjeri, povjerenju. Nadziratelj je suprotan ocu (usp. 1 Kor 4,15), a Pavao će u 3,26 reći da smo sinovi Božji. U tomu kontekstu, govor o vjeri koja je nadošla ne odnosi se na osobni čin vjere, nego na ekonomiju, rasporedbu vjere, rasporedbu spasenja koja je suprotna rasporedbi Zakona: »A otkako je nadošla vjera, više nismo pod nadzirateljem« $(3,25)$. U ovoj rečenici koja je izrečena u pobjedničkom tonu jasno dolazi do izražaja Pavlovo shvaćanje oslobođenja. Oslobođenje se ostvaruje kao sloboda od Zakona kao nadziratelja koji ljude drži u stanju maloljetnosti i koji je privremen. ${ }^{20} \mathrm{U}$ nastavku će ga razviti. Situaciju ropstva će opisati u 4,1-3, a kraj toga ropstva bit će izražen u 4,5.7. Poslije će se još na to vratiti u 4,21-31; 5,1 i 5,13.

Sloboda je vezana uz sinovstvo: ${ }^{21}$ »Svi ste naime sinovi Božji po vjeri u Krista Isusa« $(3,26)$. Nije riječi o bilo kojem sinovstvu, jer ljudsko sinovstvo ne isključuje nadziratelja. Njega, štoviše, angažira upravo otac. Riječ je o sinovstvu Božjemu, ali ne onakvom o kakvom se govorilo u Staromu zavjetu, nego o si-

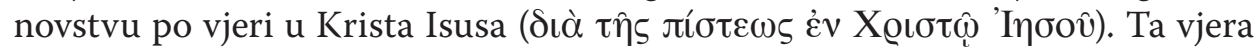

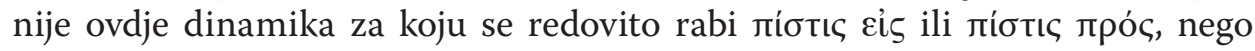
nešto stabilno, temeljno ( $\dot{\varepsilon} v)$. Radi se o vjeri kojoj je Krist temelj. Budući da je Krist sin Božji (usp. 1,6; 2,20; 4,4), i za onoga koji stoji u njemu i na njemu kao temelju može se reći i jest sin Božji. Pristajući uz Krista i to po krštenju $(3,27),{ }^{22}$ događa se transformacija osobnosti (»Kristom se zaodjenuste«, 3,27), ne samo ponašanjem koje nalikuje Kristovom i koje će tek uslijediti, ne imajući iste osjećaje/misli kao Krist (usp. Fil 2,5), nego ontičkom promjenom novoga stvaranja u Kristu. Tu je promjenu Pavao izrazio već u 2,19 kad je rekao: »Ja Zakonu umrijeh da Bogu živim. « $^{23}$ Zaodjenuti se Kristom znači, kako se to kasnija teologija izrazila, biti sinovi u Sinu. Umrijeti Zakonu znači ući u sinovski odnos s Bogom i živjeti Bogu.

\footnotetext{
${ }^{20}$ Poslanica Galaćanima ustrajava upravo na toj slobodi jer se pojam "grijeh« ( $\left.\dot{\alpha} \mu \alpha \varrho \tau i ́ \alpha\right)$

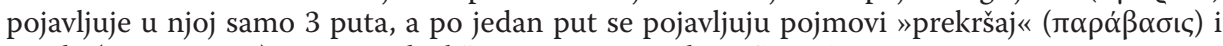

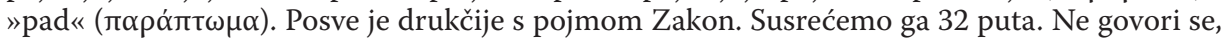
dakle, toliko o slobodi od grijeha, koliko o slobodi od Zakona.

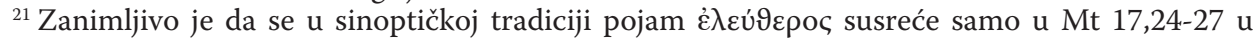
kontekstu govora o potrebi (ne)plaćanja poreza. I ovdje on određuje sinove: »Sinovi su, dakle, oslobođeni« (r. 26). To znači da je kombinacija sinovstva i slobode tipičan novozavjetni motiv.

${ }^{22}$ Zanimljivo je da Pavao baš ovdje gdje želi isključiti obrezanje, dakle izvanjski obred kao znak pripadnosti Bogu, izrijekom progovara o krštenju. Očito je stoga da krštenje ne shvaća kao izvanjski obred, nego kao opredjeljenje za zajedništvo s Bogom u Kristu koje se postupno aktualizira u vjerniku.

${ }^{23}$ Pavao gotovo nikada ne govori o smrti Zakona, nego uvijek o smrti čovjeka u odnosu na Zakon. Kada to u Rim 7,1-3 tumači slikom odnosa muža i žene, odnosno govori o ženi koja je slobodna od Zakona kada joj umre muž, iskače iz slike i zaključuje: »Tako, braćo moja, i vi po tijelu Kristovu umrijeste Zakonu da pripadnete drugomu, Onomu koji je od mrtvih uskrišen, te plodove donosimo Bogu« $(7,4)$.
} 
Sinovski odnos sve ljude povezuje i tvori od njih »jednoga« (»Svi ste vi Jedan u Kristu Isusu« 3,28), podrazumijeva se čovjeka, tako da nema više razlika, među koje Pavao ubraja i onu rob - slobodan. Ta potonja spada u razliku iz građanskoga života, uz razlike iz religioznoga (Židov - Grk) i osobnoga, spolnoga (muško - žensko) života. Sjedinjenost s Kristom stvara tertium genus, novo stvorenje (usp. 6,15) koje je svima dostupno. Za Pavla sloboda i ropstvo ne izražavaju društveno stanje, jer bi tada opozicija bila izražena pojmovima

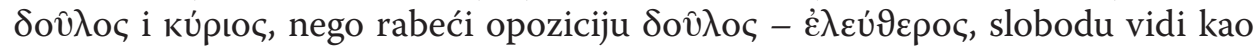
određenje bića koje nije sputano nikakvim robovanjem, nikakvom prisilom. $\mathrm{Na}$ društvenoj razini, slobodni su uživali sva politička i druga prava, a robovi su ih bili lišeni, čak i svoga osnovnoga ljudskoga dostojanstva. To društveno stanje Pavao prenosi na određenje bića. Povezanost s Kristom vraća čovjeku potpun ljudski dignitet, a njega nema bez slobode. Pavao ipak ne kaže da »nema više robova, svi su slobodni«, nego kaže da nema više »robova ni slobodnih«. Nije dakle riječ ni o kakvoj reformi društva, o ispravljanju ili dokidanju nepravdi. Riječ je o novom stvorenju, »jer tko je u Gospodinu pozvan kao rob, slobodnjak je Gospodnji. Tako i tko je pozvan kao slobodnjak, rob je Kristov. Otkupninom ste kupljeni: ne budite robovi ljudima« (1 Kor 7,22-23). U Kristu je dakle čovjek istodobno i rob i slobodan, ili, bolje rečeno, ni rob ni slobodan. ${ }^{24} \mathrm{Te}$ su kategori-

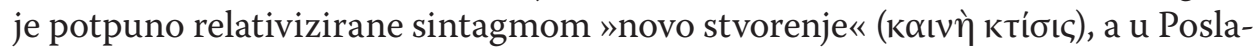
nici Filemonu Pavao će pokazati da promjena mentaliteta nužno i progresivno mijenja i ljudske strukture: roba se prihvaća kao brata. Promjena struktura nikada ne donosi slobodu, ${ }^{25}$ nego promjena čovjeka ${ }^{26}$ donosi i promjenu struktura. U Kristu oslobođeni čovjek može mijenjati i mijenja i strukture društva.

\footnotetext{
${ }^{24} \mathrm{~S}$ takvom idejom jasno je da ne misli na neko slobodarsko društvo, na sustav slobode čiju bit tvori sustav relativnih stajališta. Takvu slobodu, gdje su sva stajališta jednakovrijedna, na neki način zastupa pluralistička teologija religija [usp. Mariasusai DHAVAMONY, Teologia delle religioni, u: René LATOURELLE, Rino FISICHELLA (ur.), Dizionario di Teologia fondamen-

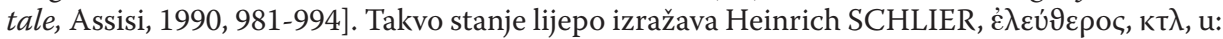
Theologisches Wörterbuch zum Neuen Testament, III, 423-468, opisujući ga kao »nepodvrgnutost ikomu u odnosu na slobodu«, a »podvrgnutost svakomu u odnosu na ljubav« (466).

${ }^{25} \mathrm{U}$ takvom pokušaju J. Ratzinger vidi temeljni promašaj latinskoameričke teologije oslobođenja koja je na nov, uvjerljiv i praktičan način ponudila odgovor na pitanje o otkupljenju. Najbolje je navesti njegov tekst: »Teologija oslobođenja je rekla, imajući u vidu ta naša iskustva (siromaštvo, tlačenje, vladavinu nepravde, trpljenje pravednih i nedužnih, o. m.): Ovo stanje, koje ne smije ostati, može biti prevladano samo po radikalnoj promjeni struktura našeg svijeta koje su strukture grijeha, strukture zla. Ako dakle grijeh vrši svoju vladavinu preko struktura, a pad u bijedu unaprijed je programiran polazeći od njih, onda se njihovo prevladavanje ne može dogoditi po pojedinačnome obraćenju, nego samo borbom protiv struktura nepravde. Ta pak borba, reklo se, mora biti politička borba jer se strukture učvršćuju i održavaju preko politike. Tako je otkupljenje postalo političkim procesom za koji je bitne putokaze pružila marksistička filozofija« (Josef RATZINGER, Vjera - Istina - Tolerancija. Kršćanstvo i svjetske religije, Zagreb, 2004, 103s).

${ }^{26}$ Ta promjena koju izriče sintagma »novo stvorenje« ne izražava nikakvu kozmološku novost, nego kristološku i ujedno antropološku novost. Ostvaruje je Bog u Kristu imajući u vidu čovjeka (usp. Ulrich MELL, Neue Schöpfung. Eine traditionsgeschichtliche und exegetische Studie zu einem soteriologischen Grundsatz paulinischer Theologie, Berlin - New York, 1989, 324).
} 
Neslobodu ili ropstvo Pavao promatra i s juridičke točke gledišta i uspoređuje je s maloljetnikom koji je gospodar svega, ali ničim ne raspolaže do dana koji je odredio otac. Život pod skrbništvom, a to je život pod Zakonom, jednak je životu u neslobodi (usp. 4,1-2). Takvo stanje primjenjuje i na one koji su u Kristu a inzistiraju na Zakonu. I oni su maloljetni i u ropskom statusu ( $\delta \varepsilon \delta o u \lambda \omega \mu \varepsilon ́ v o l, 4,3)$, podvrgnuti su elementima, počelima svijeta. Međutim, u punini vremena, slanjem svoga Sina koji je od žene rođen i podložan Zakonu, Bog je podložnike Zakona otkupio i dao im posinstvo za koje svjedoči isti Duh sinovstva kojim se obraćaju Bogu kao i Sin: $A b b a$, Oče! Po sinovstvu nema više robovanja, isključenosti iz baštine, nego se baština prima od Boga (usp. 4,3-7). Da bi maloljetnik, koji je već sin, postao baštinik, potreban je samo protok vremena, a da bi kršćani postali baštinici, oni tek trebaju postati sinovima, a to ne postaju protokom vremena nego Božjim zahvatom. Božji zahvat je već ostvaren u Kristu, tako da zaziv Abbà kod onih koji su obdareni Duhom sinovstva nije, kako neki tumače, krik za slobodom, nego izraz već dobivene slobode.

Pavao je shvatio da vjera $\mathrm{u}$ Krista prenosi čovjeka na potpuno novu religioznu razinu. Vjerovati u Kristu znači ne biti više podvrgnut prirodnim i kozmičkim silama, stvorenim stvarnostima. Pravi odnos s Bogom je osoban, u osobnoj slobodi i univerzalnoj ljubavi. Iz te perspektive, oni koji su još pod Zakonom nalaze se u nekom rudimentarnom stanju. I Zakon je ljude, najprije Židove, a onda i kršćane koji ga gledaju kao jednakovrijedna Kristu, stavljao u ropstvo, pod prisilu materijalnim i kozmičkim elementima i počelima te ih je u tomu smislu držao u situaciji koja je jako slična onoj pogana.

Sin Božji, rođen od žene, podložan Zakonu po tomu što je rođen kao Židov, otkupljuje podložnike Zakona, očito, stanovitom cijenom. Zato Pavao ovdje rabi glagol $\grave{\varepsilon} \xi \alpha \gamma o \rho \alpha ́ \zeta \omega$, a ne glagol »osloboditi«, premda su značenjski isti. Otkupna cijena je njegovo posvemašnje podlaganje Zakonu do smrti koju mu je Zakon dosudio. Poslije toga Zakon više nema nad njim nikakvu moć. Da je ostao u smrti, ostao bi trajno pod vlašću Zakona, čime bi Zakon bio potvrđen kao gospodar života i smrti. Međutim, njegova smrt podnesena iz sinovske poslušnosti i bratske ljubavi transformirala je njegovo umiranje u umiranje Zakonu za svoju braću. On sam kao osloboditelj, oslobođen je od smrti koju je pretrpio. Njegova smrt je za braću, zastupnička, proegzistentna, oslobađa od podložnosti Zakonu i otvara mogućnost osobne relacije s Bogom, takve koja više ne ovisi o Zakonu nego je izraz sinovstva.

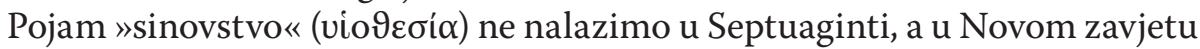
ga nalazimo samo kod Pavla (Gal 4,5; Rim 8,15.23; 9,4). Sinovstvo je izraz obdarenosti Duhom i Duh svjedoči za njega. To je Duh Sina Božjega koji iznutra mijenja čovjekovo srce (usp. Ez 36,26s), što Pavao potvrđuje i u Rim 8,14: »Koje vodi Duh Božji, sinovi su Božji« i u Rim 8,16: »Sam Duh svjedoči našem duhu da smo sinovi Božji.« Ipak, u Gal 4,6 govori o »Duhu Sina svoga koji kliče: 'Abba! Oče!'« što je jedinstven izraz u Novom zavjetu. ${ }^{27}$ Duh je u uskoj povezanost s

\footnotetext{
${ }^{27}$ Usp. Romano PENNA, Lo Spirito di Cristo, Brescia, 1976, 207-236.
} 
Bogom, koji ga šalje kao i Sina, ali i sa Sinom kojemu pripada. Po njemu smo u odnosu sa Sinom i sa samim Bogom. Sinovski odnosi su osloboditeljski, jer

»ne primiste Duha robovanja da se opet bojite, nego primiste Duha posinstva u kojem kličemo: 'Abba! Oče!' Sam Duh susvjedok je s našim duhom da smo djeca Božja; ako pak djeca, onda i baštinici, baštinici Božji a subaštinici Kristovi, kada doista s njime zajedno trpimo, da se zajedno s njime i proslavimo« (Rim 8,14-17).

Robovanje i strah, izrazi neslobode, suprotstavljeni su tu Božjemu sinovstvu koje je temelj i izraz slobode.

Zanimljivo je da stanje otkupljenosti, oslobođenosti od Zakona Pavao veže uz Duha. Duh je najzagonetnija kategorija Novoga zavjeta, a u biti uvijek mu u pozadini stoji dah, zrak, impuls, snaga. Duh je u konačnici relacija, kao što je i zrak. Tko hoće zrak zadržati samo za sebe, morat će se hermetički zatvoriti, izolirati i u tomu će konačno umrijeti ako se ne otvori zraku koji svi drugi dišu. Zrak pripada svima i nitko njime ne može manipulirati. Iz toga je vrlo jasno poimanje slobode u Duhu. Prava se sloboda realizira tek onda kada su svi slobodni. Rezervirati je samo za sebe ili samo za neke znači opredijeliti se za smrt. Sloboda se ne ostvaruje dominacijom nad drugima, ${ }^{28}$ oduzimanjem tuđe slobode, ne na račun drugih, nego u jedinstvu s drugima.

Božjega se Duha prima po Kristu, a to znači da je to Duh koji daje život obilježen Kristovim otajstvom, njegovim prihvaćanjem smrti iz poslušnosti Ocu i ljubavi prema braći, a to je isti Duh »onoga koji je uskrisio Isusa od mrtvih« (Rim 8,11). Prava sloboda od Zakona koju je Krist darovao u konačnici je sloboda za smrt i uskrsnuće. Duh sinovstva u konačnici jedini je koji oslobađa, jer: »Niste primili Duha ropstva« (Rim 8,15) ili: »Gdje je Duh Gospodnji, tu je sloboda« (1 Kor 3,17). Tu slobodu kršćani već imaju, ali ona još nije potpuna, još nije »sloboda slave djece Božje« (Rim 8,21). Budući da je Duh izvor slobode, njezin djelatnik, sloboda je označena time kao nova egzistencijalna situacija, kao ontička promjena i ulazak u familijaran odnos s Bogom. ${ }^{29}$

Dojam da se spasenje postiže po Zakonu najveća je pobjeda grijeha koji ujarmljuje Zakon u svoje svrhe. Spasenje se postiže ljubavlju koja dolazi iz vjere, a onda će i Zakon imati svoju vrijednost. Zakon se ne odbacuje, nego ga se s ljubavlju i u ljubavi ostvaruje. Sloboda je sloboda za ispunjenje Zakona u ljubavi. To je sloboda za Boga i bližnjega, inače je Krist uzalud umro. Zakon je, a to Pavao otkriva tek u Kristu, »životni temelj i horizont neotkupljene stvarnosti svih

\footnotetext{
${ }^{28}$ Jürgen MOLTMANN, Gott im Projekt der modernen Welt. Grundzüge menschlicher und christlicher Hoffnung, u: Katholische socialethische Arbeitsstelle. Grundwert Hoffnung, Hamm, 1982, 143-149, razlikuje slobodu kao »dominaciju« i kao »komunikativnu slobodu«. Sloboda nije posjed nego kvaliteta međuodnosa. Iz nje proizlazi sloboda kao »stvaralačka težnja za mogućim «, sloboda koja nije usmjerena samo na stvari i osobe nego na novu budućnost.

${ }^{29}$ Usp. Giuseppe BARBAGLIO, Alle comunità di Galazia, u: isti, Le lettere di Paolo, Rim, ${ }^{2} 1990$, II, 9-167, 123.
} 
ljudi, Židova i pogana«. ${ }^{30}$ Ipak: »Sloboda od Zakona kao jedinog puta k spasenju jest istovremeno sloboda za zakon kao sadržajnu zapovijed«(W. Schrage). ${ }^{31}$ Takva sloboda priliči punoljetnosti, sinovstvu i odgovornosti. Ona čini da »staro uminu, novo, gle, nasta!« (2 Kor 5,17).

Novost o kojoj Pavao govori novost je Kristova gospodstva i snage njegova Duha. Po njima i Zakon može biti sredstvom Božje milosti, jer Duh ne oslobađa od samoga Zakona ni od Pisma, nego od slova ( $ү \rho \alpha ́ \mu \mu \alpha)$ i njegova "prokletstva« $(3,13)$. Prokletstvom se izražava ono što je Zakon bez Krista i njegova Duha slovo koje zarobljava i ubija.

\section{Zaključak}

Pavao se na različite načine potrudio pokazati koliko je Zakon u suprotnosti sa slobodom koju donosi vjera u Krista. Najprije u Abrahamu, koji slovi kao paradigmatski model odnosa s Bogom, pokazuje prednost vjere i obećanja pred Zakonom i njegovim vršenjem. Oslanja se na Pismo i njegove iskaze o Abrahamu i vještim egzegetskim postupkom pokazuje i dokazuje da je Bog od samih početaka spasenjske povijesti predvidio vjeru kao put spasenja, a ne Zakon. Zakon je naknadno dodan radi prekršaja i kao takav ima posredničku ulogu u oslobađanju čovjeka, štoviše, držao je čovjeka kao maloljetnika u ropstvu. Bio je nadziratelj, onaj koji čuva, stražari, prisiljava, zarobljava, jednostavno oduzima slobodu koja se dobiva tek po vjeri, povjerenju. Nadziratelj je skrbnik, privremen je i suprotan ocu (usp. 1 Kor 4,15), a Pavao tvrdi da su oni koji su u Kristu sinovi Božji (usp. 3,26), da im je Bog otac. Sloboda je vezana uz sinovstvo u kojemu nema više robova ni slobodnih. Ona nije plod nikakvih reformi društva, ispravljanja ili dokidanja nepravdi. Obilježava novo stvorenje, »jer tko je u Gospodinu pozvan kao rob, slobodnjak je Gospodnji. Tako i tko je pozvan kao slobodnjak, rob je Kristov. Otkupninom ste kupljeni: ne budite robovi ljudima« (1 Kor 7,22-23). U Kristu je, dakle, čovjek istodobno i rob i slobodan, ili, bolje rečeno, ni rob, ni slobodan. Stanje sinovstva i otkupljenosti, oslobođenosti od Zakona Pavao veže uz Duha. Takvim vezivanjem upućuje na zaključak da se istinska sloboda realizira tek onda kada su svi slobodni. Rezervirati je samo za sebe ili samo za neke znači opredijeliti se za smrt. Sloboda se ne ostvaruje dominacijom nad drugima, oduzimanjem tuđe slobode, ne na račun drugih, nego u jedinstvu s drugima. Zakon zarobljava jer dijeli ljude, upućuje ih na oslanjanje samo na sebe i svoja djela, a Krist oslobađa jer upućuje na vjerničko oslanjanje na Božje obećanje, u konačnici na Božju moć uskrisavanja mrtvih i darivanja novoga stvorenja. U Kristu je nastupila sloboda od prokletstva Zakona, od njegove prisile koja dokida Božje obećanje.

\footnotetext{
${ }^{30}$ Günter BORNKAMM, Paulus, Stuttgart, 1969, 131.

${ }^{31}$ Navedeno prema Porsch, Mnogo glasova..., 161.
} 


\section{Marinko Vidović* \\ »It is for Freedom that Christ has Set us Free« (Gal. 5: 1) - Conception of \\ Freedom in the Epistle to the Galatians \\ (Second Part: Freedom as Freedom from the Law of Moses)}

\section{Summary}

Since the faith, and thus the freedom of the Galatians, is threatened by the attempt to return to the Law of Moses, relying on the biblical narrative of Abraham, Paul speaks of freedom as freedom from the Law of Moses. His basic claim is that the Law is not the beginning of the history of salvation, but Abraham's faith, which relied on the promise of God. In this sense, the Law was added because of transgressions, because of the infancy of mankind; it was a supervisor in terms of the temporality and certain coercion of its subordinates and it was an enslaving force of which man had to be freed. This freedom was realized by God in Christ, who is the only true Abraham's Descendant. Those who are in Christ have an Abrahamic relationship with God, a relationship of trust and reliance on the promise, a relationship of freedom which the Law did not serve but endangered it. Freedom is not realized under external compulsion, but by an inward commitment to God's conduct, carried by his promise. In this part of the paper, in the Epistle to the Galatians we follow Paul's thinking of the freedom God offers in Christ, which is based on the promise as the path to true freedom in responsibility. With Abraham as a model of God's treatment of humanity and human response to God's offer and promise, Paul defines freedom as freedom from the coercion of the Law.

Key words: Abraham, coercion, faith, freedom, law, Law of Moses, promise.

(na engl. prev. Jadranka Krajinović)

\footnotetext{
* Marinko Vidović, PhD, Full Prof., University of Split, Faculty of Catholic Theology; Adress: Zrinsko-frankopanska 19, HR-21000 Split, Croatia; E-mail: mvidovic@kbf-st.hr.
} 